\title{
ETHNOBOTANICAL STUDY OF MEDICINAL PLANTS USED IN TRADITIONAL MEDICINE IN THE PROVINCE OF SIDI KACEM, MOROCCO
}

\author{
ENNACERIE FATIMA-ZAHRA ${ }^{1}$, RHAZI FILALI FOUZIA ${ }^{1 *}$, RAHOU ABDELILAH ${ }^{2}$
}

${ }^{1}$ Department of Biology, Team Microbiology and Health, Laboratory Chemistry Biology Applied to the Environment, Faculty of Science, University Moulay Ismail, PB 11201, Zitoune, Meknes, Morocco. ${ }^{2}$ Department of Biology, Laboratory of Plant Biotechnology and Molecular Biology, Faculty of Science, University Moulay Ismail, PB 11201, Zitoune, Meknes, Morocco. Email: fouzia.filali@yahoo.fr

Received: 26 July 2016, Revised and Accepted: 24 September 2016

\section{ABSTRACT}

Objective: It's an ethnobotanical study to establish a floristic catalog of medicinal plants harvested from the province of Sidi Kacem (Morocco), which are used in traditional therapy for respiratory, digestive and skin infections

Methods: We carried out a field survey using a questionnaire sent to 200 people spread over four studied areas, previously determined by stratified sampling techniques. This survey includes a section on the informant's therapeutic practices, and another on the varieties of plants used by the population

Results: The analysis of the information found that $40 \%$ of the people surveyed practice herbal medicine. It enables us to establish a floristic catalog of 73 identified species. They belong to 39 families, the most dominant being Lamiaceae, Apiaceae and Asteraceae. The leaves are the most used part of the plant as a decoction

Conclusion: These results are new; they allowed us for the first time to create a database on the floristic characteristics and the traditional therapy of this region. They will be useful for valorizing and rationalizing them by extending studies on their chemical properties and biological activities.

Keywords: Province of Sidi Kacem (Morocco), Phytotherapy, Ethnobotanical survey, Infections, Catalogue of plants.

(C) 2017 The Authors. Published by Innovare Academic Sciences Pvt Ltd. This is an open access article under the CC BY license (http://creativecommons. org/licenses/by/4. 0/) DOI: http://dx.doi.org/10.22159/ajpcr.2017.v10i1.14326

\section{INTRODUCTION}

From dawn, humans had recourse to its environment and especially the plants to relieve his pain, cure his disease and hunt their prey. In time, he learned to identify the properties, virtues, and toxicity of several species. He inherited about information plant parts the most effective and their preparation methods. This traditional knowledge is passed from one generation to another.

Currently, despite the development of scientific research, which aims to study the properties of these medicinal plants, identifying their bioactive molecules and determining their biological and toxic activity, antimicrobial and antioxidant efficacy; traditional medicine persists universally and particularly in the developing countries among others Morocco.

The long medicinal tradition and interesting know-how of the Moroccan phytotherapy could be explained by its geographical location and the many civilizations that have followed over time. Similarly, the Mediterranean bioclimate and geographical and geological diversity allow for foster a great floristic richness, and even endemic. About 7000 species, subspecies, and varieties existing, 537 are endemic to the country, and 1625 are rare or endangered [1].

However, ethnobotanical studies that have been carried across Morocco show that the searches for medicinal plants nationwide remain regional and fragmentary [2]. Similarly, now, know-how is held by few people [3]. Under these conditions, this precious heritage of knowledge is threatened and the Moroccan floristic richness and virtues will not be valued, because, Moroccan medicinal flora is still little known until today, onto the few thousand of plant species, medicinal species recorded do not exceed $356[4,5]$ and 600 species $[6,7]$

To participate in the identification, enrichment of the Moroccan flora and its valuation, our ethnobotanical study focused on the area of Sidi
Kacem, which is rich in floral varieties and knowledge of traditional medication, but scientific studies are still not achievable. Our first objective is to inventory of the medicinal plants in the region, and especially those used against cutaneous, respiratory, and digestive infections. The second objective is to maintain this popular know-how, enhance and rationalize their use based on the traditional heritage of the local population and the recent and practical scientific studies.

\section{METHODS}

Geographic and socioeconomic framework of the study area The study area, province of Sidi Kacem, is located at the extremity of the Gharb plain Chrarda Beni Hssen. It is located at $84 \mathrm{~km}$ east of the city of Kenitra, $82 \mathrm{~km}$ North-West of the city of Fez and $46 \mathrm{~km}$ north of the city of Meknes (Fig. 1).

The province of Sidi Kacem extends over a geographical area surface of 199,909 ha with 40 municipalities whose six urban (Dar Gueddari, HAD KOURT, Jorf el Melha, Mechraâ Bel Ksiri and Sidi Kacem) and 34 rural (Babtiouka, Birtaleb, Khnichet, Zaggota, Zirara). According to the census of the year 2005, the population of Sidi Kacem was about 74,062 inhabitants and people from central Zirara were approximately 6.707 inhabitants.

The climate of the province of Sidi Kacem is continental semi-arid of temperate winter with a relatively long dry period that usually lasts from May to September. Climatic parameters of the region can be summarized in the regional office of agricultural development (Office Régionale de la Mise en Valeur Agricole ORMVAG) [9].

Maximum temperatures vary from $16^{\circ} \mathrm{C}$ to $38^{\circ} \mathrm{C}$, for minimum temperatures vary between $4^{\circ} \mathrm{C}$ and $20^{\circ} \mathrm{C}$.

- Average annual rainfall is about $420 \mathrm{~mm}$.

- Atlantic winds coming from the west and causing a decrease in the air temperature of a few degrees and an increase in the relative 


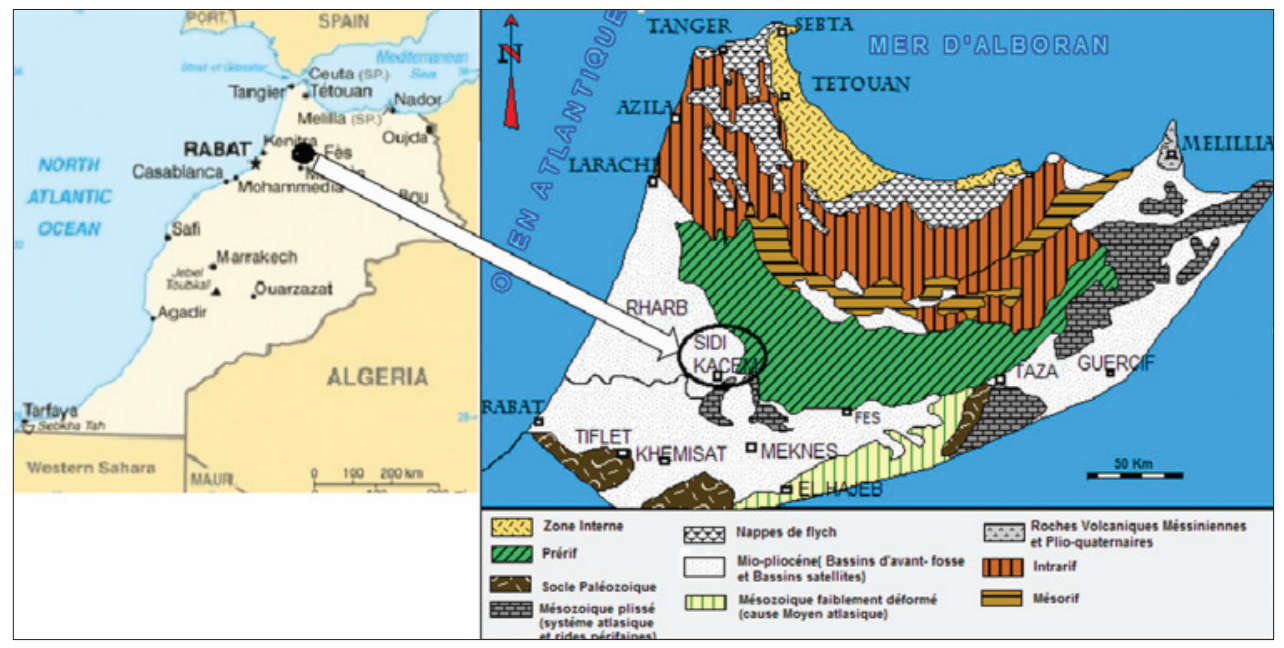

Fig. 1: Map of the geographical location of Sidi Kacem's province (Morocco) (Suter, 1980: Geological Map of the Rif 1/500000) [8]

humidity of $30-40 \%$. The East winds or Chergui the most dominant are dry and hot thus leading to an increase in the air temperature and a decrease in the relative humidity of $10 \%$.

The soil composition of the province of Sidi Kacem is of two types: The first one governs the developed raw mineral soils known by the name Dehs. They are well drained and have a generally satisfactory fertility. The second type is presented in the vertisols little evolved called the Tirs, they cover most of the area of the province (over 92\%), as they have a difficult to work them.

The hydrographic network of the study area is important; it includes surface waters, which consist of five Oueds: R'dom Oued, Ourgha Oued, Rdat Oued, and Sebou Oued. Groundwater presented in two layers, one in the South East to a depth of $350 \mathrm{~m}$, formed from clay sediments and sandy clay. The other is shallow with a level of mediocre quality, consisting of silty and sandy clays.

Given its geographical position, its economic activity, the province of Sidi Kacem is dominated by agriculture, and according to the general of population and housing census (Recensement Général de la Population et de l'Habitat, RGPH) [10], it presents $58.6 \%$ of the total. The main agricultural products of the region are grain, and vegetable gardening with their large share (tomatoes, potatoes, artichoke, melon, watermelon, pepper, and eggplant). The industrial sector has an average of $8.3 \%$ activity with a variety of stakeholders.

- Food industry is in first class order; it cites flour mills, sugar mills, oil mills, industrial Maâsras, and operating dairy cooperatives (One large modern unit production capacity of 200,000 L/day).

- Petroleum industry is represented by gasoline service stations and lubrication, depositing plant petroleum products, recent plant of deposit petroleum products (Community Storage Company CSC), wash plant and fill small bottles gas.

\section{Ethnobotanical study method}

Our ethnobotanical study includes two parts: The first on the field and the second in the laboratory. The first took place from April to December 2015. Initially, we located the various ethnobotanical surveys locations by stratified sampling techniques "probabilistic stratified" (Kahouadji, 1986) [11], which aim to have a floristic inventory as complete as possible and to conduct surveys in different parts of the study area [12].

The tool of this study is a survey of 200 records to fill from the direct interrogation of the local population. It allowed us to collect important information about the informant and the plants used for the treatment of skin, respiratory, and digestive infections. Thus, the data for each investigated include age, sex, academic level, family status, and type of medication. The information collected for each plant contain the common name, type (wild, cultivated, weed), uses, the part used, method of preparation.

As regards sampling selected, it is a simple random type. The area was divided into four layers corresponding to the number of municipalities (city Sidi Kacem, Maachraâ Bel Ksiri, Dar Gaddari, Jorf El Melha). Each stratum is represented by 50 people, and the aggregate sample of 200 people.

The data collected on the records are then entered into a database and processed by Excel spreadsheet software.

The second part of this ethnobotanical study is the taxonomic identification of species collected during the floristic surveys. It was realized later in the laboratory (Laboratory of Plant Biotechnology and Molecular Biology), Faculty of sciences in Meknes, using botanical books available [13-17].

\section{RESULTS}

The results of this study are collected and classified according to the following aspects:

\section{Sociodemographic data of respondents Use of medicinal plants by age}

Practitioners of traditional medicine of the region of Sidi Kacem were classified into three groups according to age intervals. Fig. 2a shows that people who have exceeded the age of 45 years have a high frequency of use of medicinal plants $(45.36 \%)$, followed by people who aged between 30 and 45 years (34.02\%), whereas young people from 16 to 30 years old are in last place class (20.62\%).

\section{Use of medicinal plants according to sex}

The survey of the local population in the region of Sidi Kacem revealed that both women and men all practice traditional medicine. They use herbs to heal various skin, digestive or respiratory infections. However, we note the dominance of women by $78 \%$ compared to men $22 \%$ (Fig. 2b).

\section{Use of medicinal plants according to the academic level}

At region-wide of Sidi Kacem, we note from Fig. 2c, that good portion of people who use medicinal plants against the three studied infections, they are illiterate with $42.11 \%$. However, people who have a secondary level, have a significant (32.63\%) followed by those of primary level $(13.68 \%)$. Finally, the academic training who uses very little medicinal plants is about $10.53 \%$. 


\section{Choice of herbal medicine and modern medicine}

Thirty-nine percent of citizens of the province of Sidi Kacem treat skin, respiratory, and digestive infections by herbal medicine. While more than half (56\%) use traditional and modern medicine and just 5\% who believe in medicine (Fig. 2d).

\section{Ethnobotanical and pharmacological data}

Used parts of the plants selected

Analysis of the information collected, reveals that the most used part of medicinal plants is the foliage with a $44.89 \%$, followed by the whole plant (23.46\%) and seeds (14.28\%) (Fig. 3). While other parts of the plant, namely, stem, fruit, bark, rhizome, root, bulb, and flower, are represented by a cumulative $17.37 \%$.

\section{Method of preparation of the plant}

In the study area, the most frequent method of preparation (Fig. 4) for the treatment of skin infections is cataplasm (48.15\%), followed by raw preparation $(22.22 \%)$, and finally infused the decoction and cooked presenting $(29.62 \%)$. As for digestive infections, traditional practitioners often use the decoction (41.18\%), raw (27.45\%), and infused $(25.49 \%)$. Other preparation methods are cumulative (5.88\%).
As for respiratory infections, the method of treatment is almost divided between the infused (47.06\%) and the decoction (41.18\%), while raw reached $(11.76 \%)$.

\section{Dose used}

The ethnobotanical study revealed that the local population does not use a precise dose when preparing their phytodrugs. More than half of users (55\%) weighed with the spoon, then come weighed handle (33\%), pinched and glass respectively (7\%) (5\%) (Fig. 5a).

\section{Source of information}

Although the variety of sources of information about the species of medicinal plants and their modes of preparations the inherited form constitutes dominance: $85.57 \%$ of the population of Sidi Kacem, to relieve their pain, refers to the experiences of antecedents as the origin of the information. The second origin is presented in the media, especially radio with a frequency of $9.28 \%$. Other ways citing books and herbalists are represented by a cumulative $5.15 \%$ (Fig. 5b).

\section{Floristic analysis}

In general, the analysis of the collected information floristic allowed identifying 73 plant species distributed in 39 botanical families.

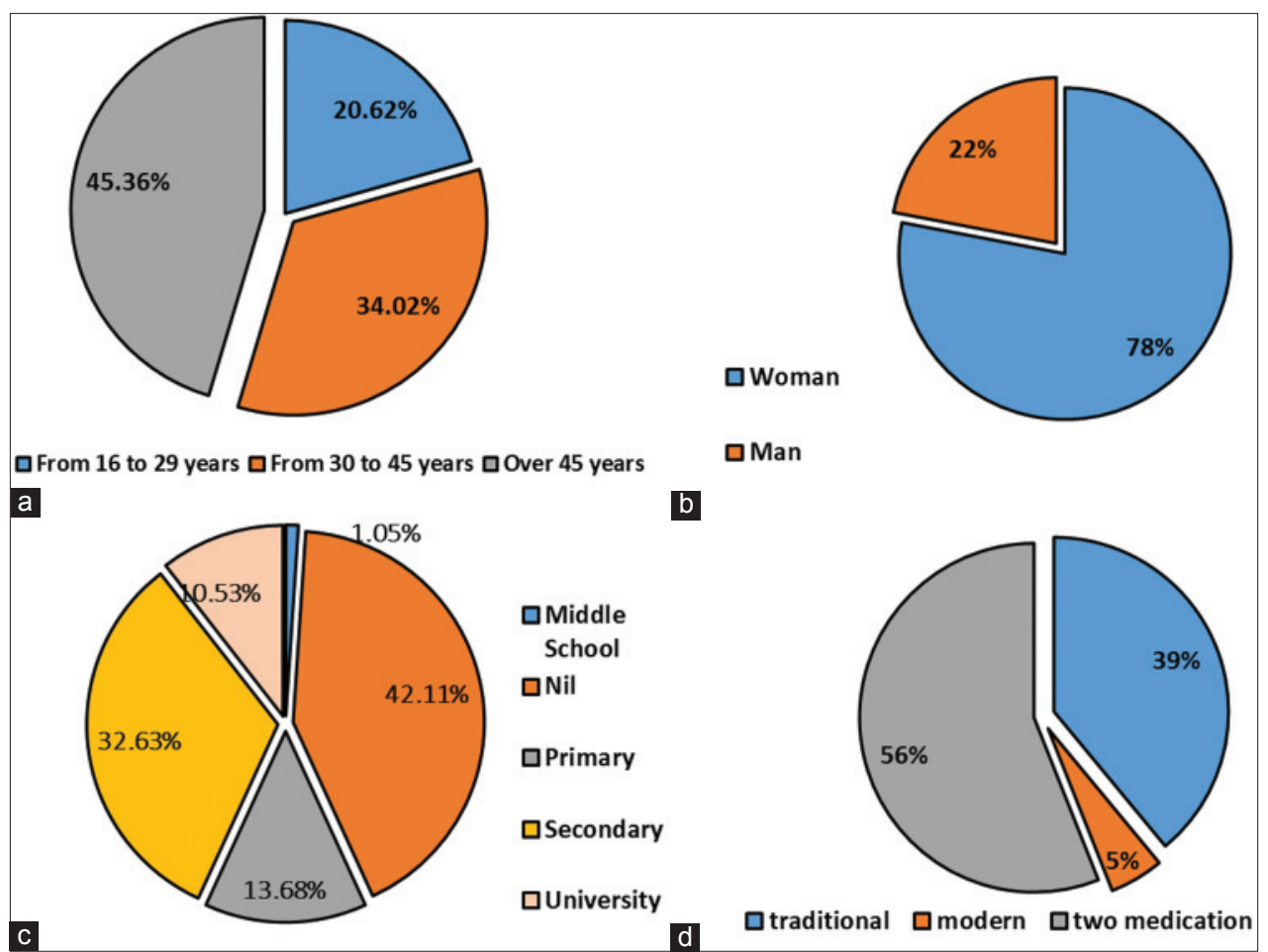

Fig. 2: Distribution of respondents according to: (a) Age; (b) Sex; (c) Academic level; (d) Type of medication

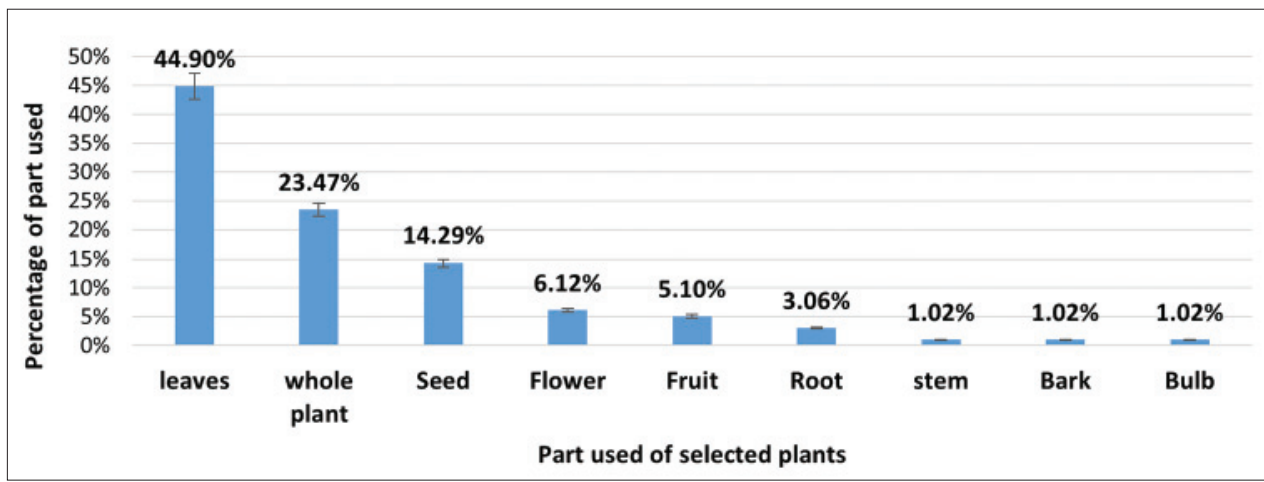

Fig. 3: Distribution of parts used selected plants 


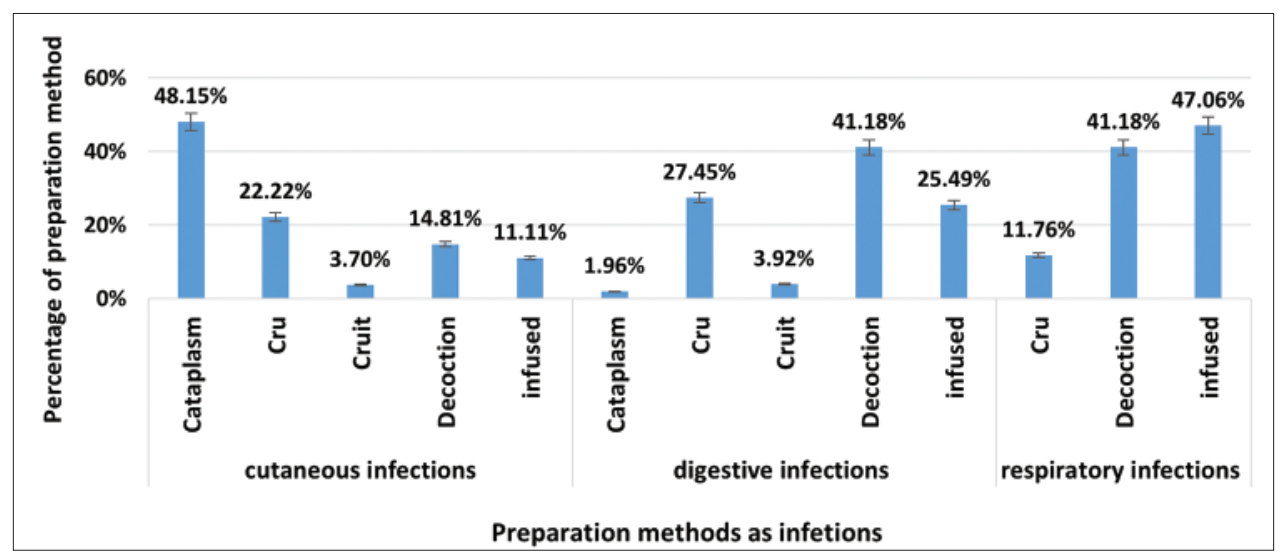

Fig. 4: Distribution of preparation methods as infections

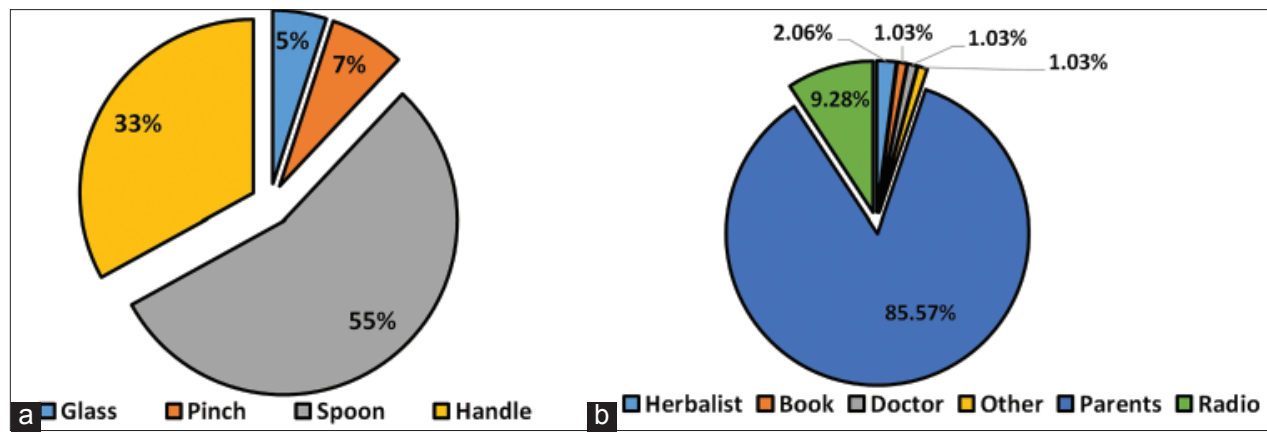

Fig. 5: Distribution of: (a) Dose used; (b) Source of information

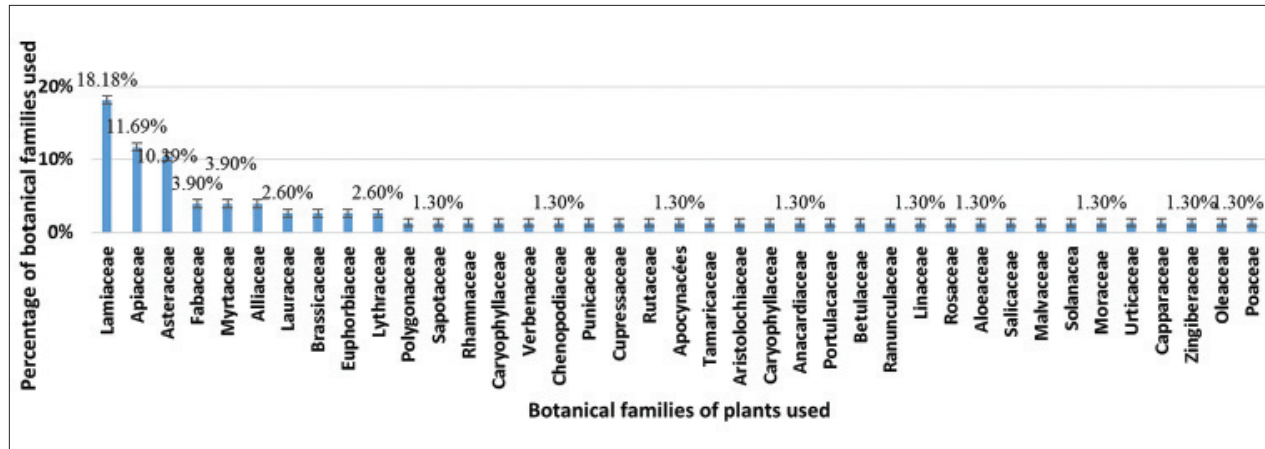

Fig. 6: Distribution of families of plants used

The most represented families are the Lamiaceae (14 species) Apiaceae (9 species) and Asteraceae (8 species) with $17.95 \%$, respectively, $11.54 \%$ and $10.26 \%$ of the inventory (Fig. 6).

As for the floristic study of medicinal species used against each of the three types of infection, it revealed the diversity of medicinal plants of the region and the wealth of herbal medicine in this region.

\section{Skin infections}

The analysis, of the information collected, shows that skin infections in the region of Sidi Kacem are treated by 37 species divided into 22 families, of which five are the most dominant. They include 19 species representing $86.36 \%$ of the total workforce.

The five dominant botanical families are listed as follows:

- The Lamiaceae $(20.00 \%)$, they bring together seven species forming 18.91\%;

- The Asteraceae (11.43\%) with four species: $10.81 \%$;

- The Apiaceae (8.57\%) with three species: $8.10 \%$;

- The Alliaceae (8.57\%) with three species: $8.10 \%$;
- The Lythraceae (5.71\%)with two species: 5.4\%;

Other botanical families used against this type of infection have $<5 \%$ and are grouped in Fig. 7.

\section{Respiratory infections}

The information acquired from the questionnaire sheets and statistical processing, helped us to establish a graph (Fig. 8). This shows that the most used botanical families to relieve respiratory infections by respondents are four in number. They are classified according to their importance:

- The Lamiaceae $(26.67 \%) 8$ species

- Asteraceae (13.33\%) 4 species

- The Alliaceae (6.67\%) 2 species

- The Myrtaceae (6.67\%) 2 species.

The other 13 families represent a cumulative frequency of $43.33 \%$.

\section{Digestive infections}

The exploitation of survey data identified and designated in Sidi Kacem 24 botanical families used to treat digestive infections. Apiaceae and Lamiaceae 


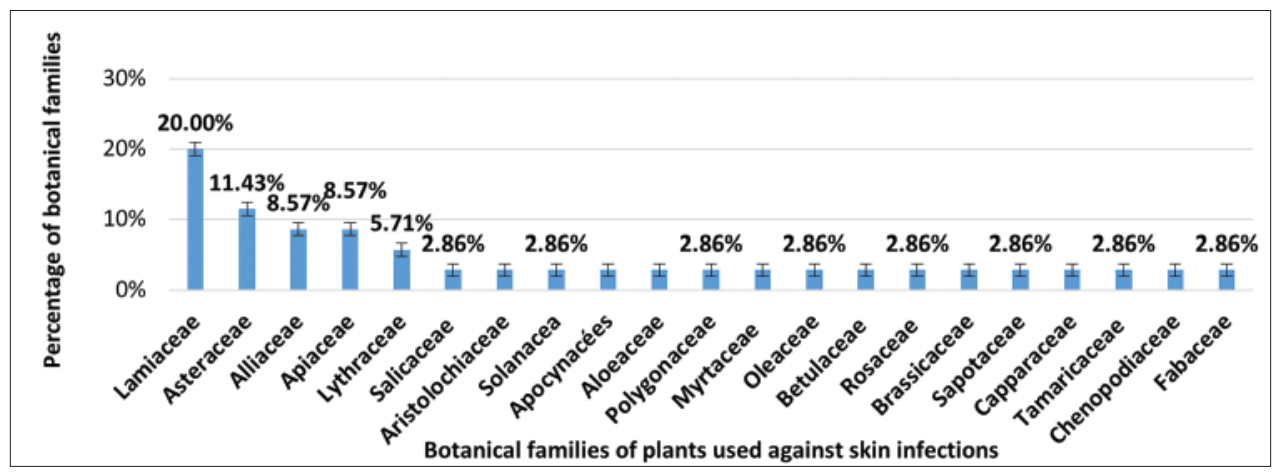

Fig. 7: Distribution of families of plants used against skin infections

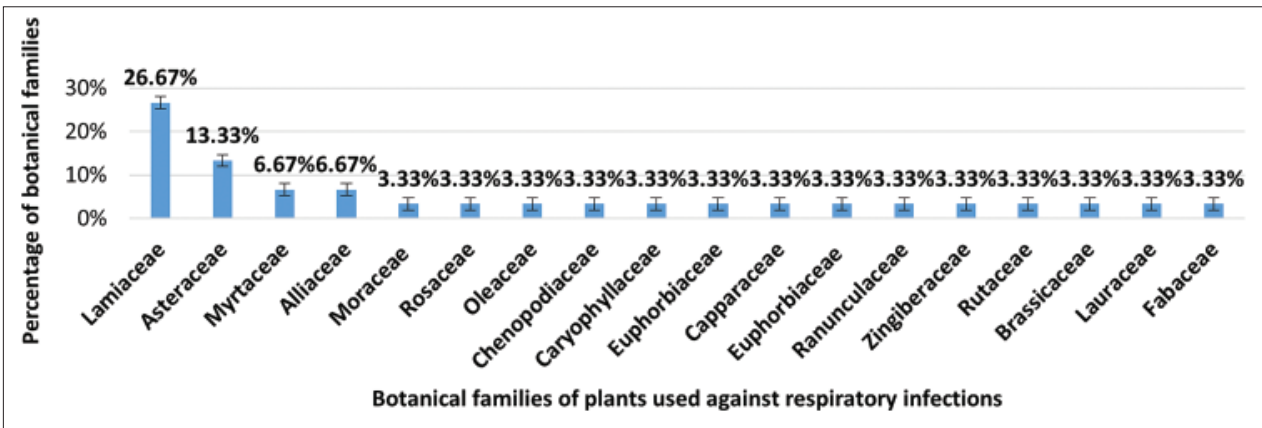

Fig. 8: Distribution of families of plants used against respiratory infections

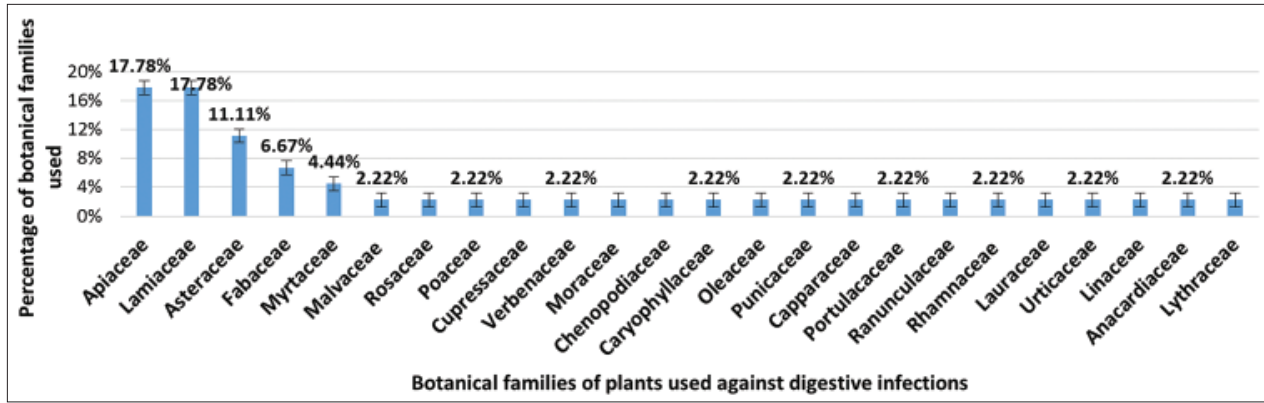

Fig. 9: Distribution of botanical families used against digestive infections

are two families predominantly used (8 species, 17.78\%) for each, then comes the Asteraceae ( 5 species, $11.11 \%$ ) and Fabaceae ( 3 species, 6.67\%), and finally the Myrtaceae ( 2 species, 4.44\%). Other families intervene by a single species and have a cumulative $42.18 \%$ (Fig. 9).

\section{DISCUSSION}

This study had for objective to identify the plants used in the treatment of skin, respiratory and digestive infections. The ethnobotanical survey was carried out involving 200 traditional practitioners in the region, who were predominantly women and mature over 45 years old. This profile is observed in most studies of the same type. The case of ethnobotanical study in the eastern High Atlas [7], in the Prefecture of Agadir Ida Outanane Morocco [2], in the region of Mechraâ Bel Ksiri [3], and forest Amsittène (Province of Essaouira) [18]. These results are explained, on the one hand, by the family status of women and its culinary and health responsibility of all household members. Women are traditionally the custodians of the secrets of medicinal plants [7]. On the other hand, it can be explained by the mistrust of young people, who tend to not believe in the medicinal effect of plants. As well as, in Warangal district, Telangana, and India, the young people have no interest to use traditional medicine and are unable to mention a large number of medicinal plants compared with to the elders [19]. Thus, it is clear that the traditional knowledge is acquired with the repetitive experience and the transmission of information from parents to children.

As many of the citizens of the study area resort to traditional medicine and especially the category of illiterates, they use more medicinal plants, compared to those with university academic level who have a tendency towards a prescribed therapy staff modern medicine. This reflects the special place of medicinal plants in their lives. In addition, the socioeconomic side, can also include in this context, a large portion of the population, of the study area, does not have a sufficient income that allows them to cover the costs of medical care. These results confirm the ethnobotanical study carried nationwide, at the prefecture of Agadir Ida Outanane [2], at Mechraâ Bel Ksiri [3], and the forest Amsittene of the province of Essaouira [18].

Despite the diversity of medicinal plants and the variety of diseases, the leaves are the part most used by the population. This result is the same as in many studies established in morocco $[2,3,7,18,20]$ and the South of Côte d'Ivoire [21]. The high use of this organ of the plants by the population can be explained by its major role in photosynthesis, its relevant secondary metabolites. Since the concentration of a large number of groups of bioactive molecules tannins, alkaloids, flavonoids, 


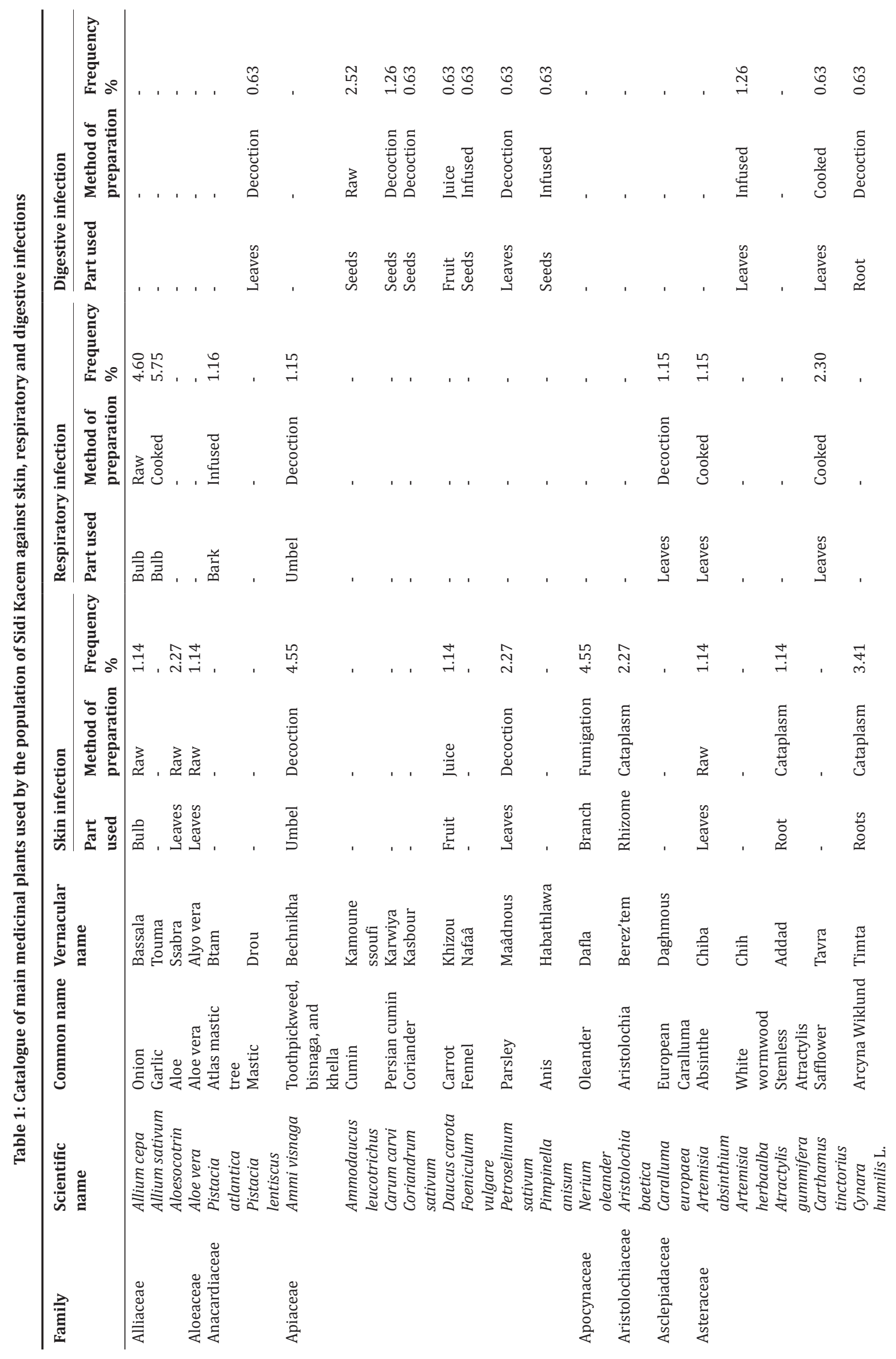




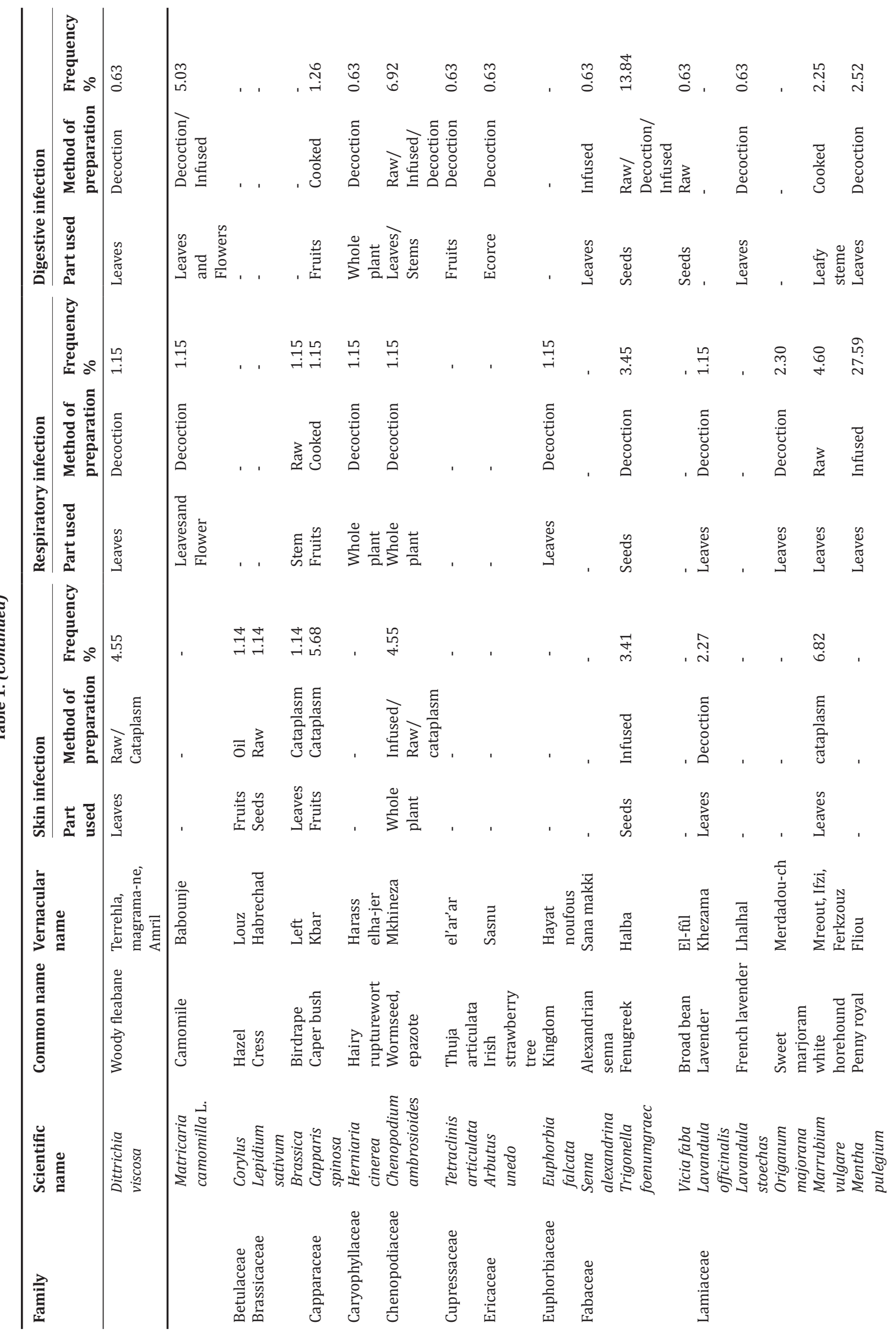




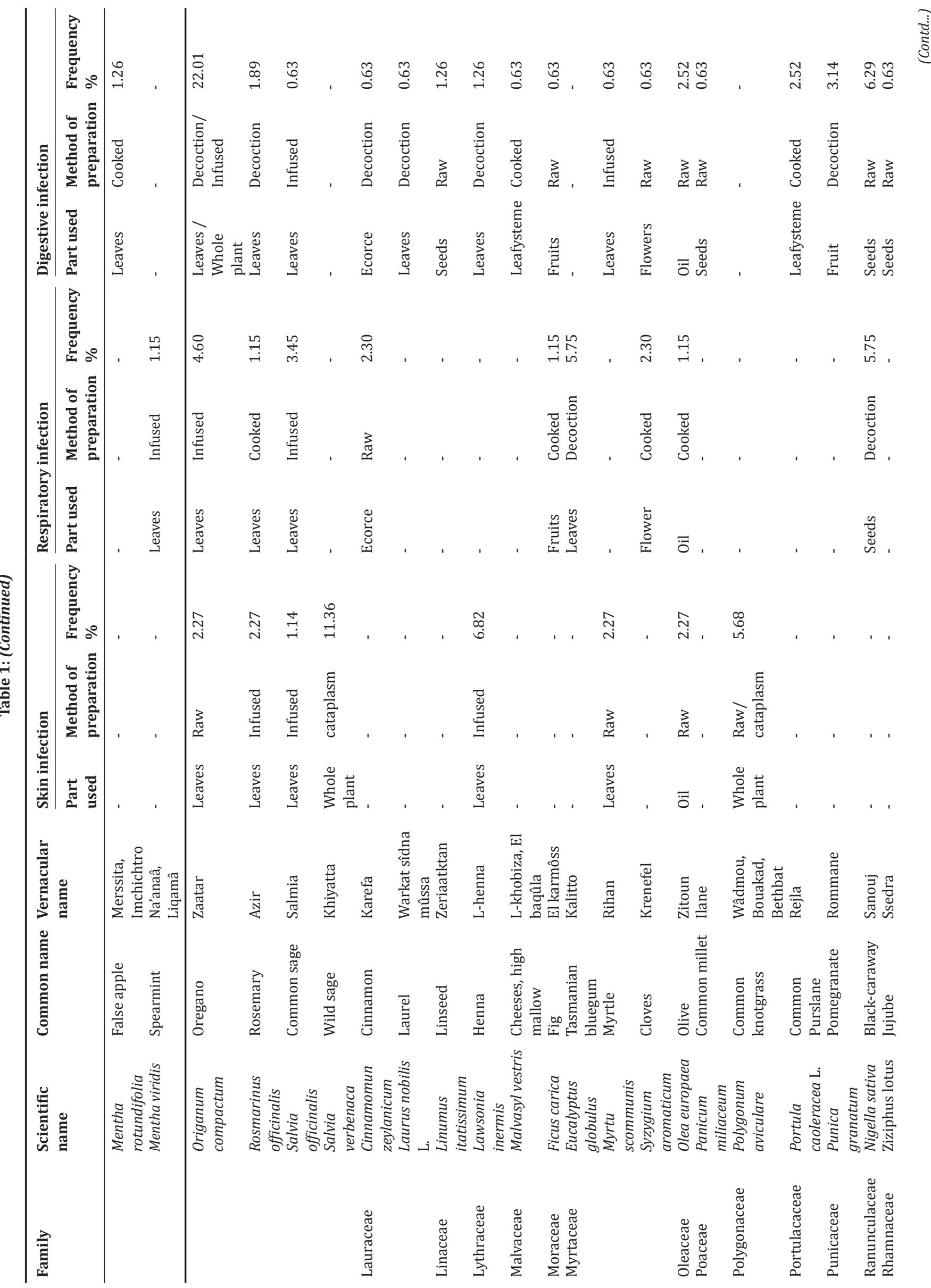




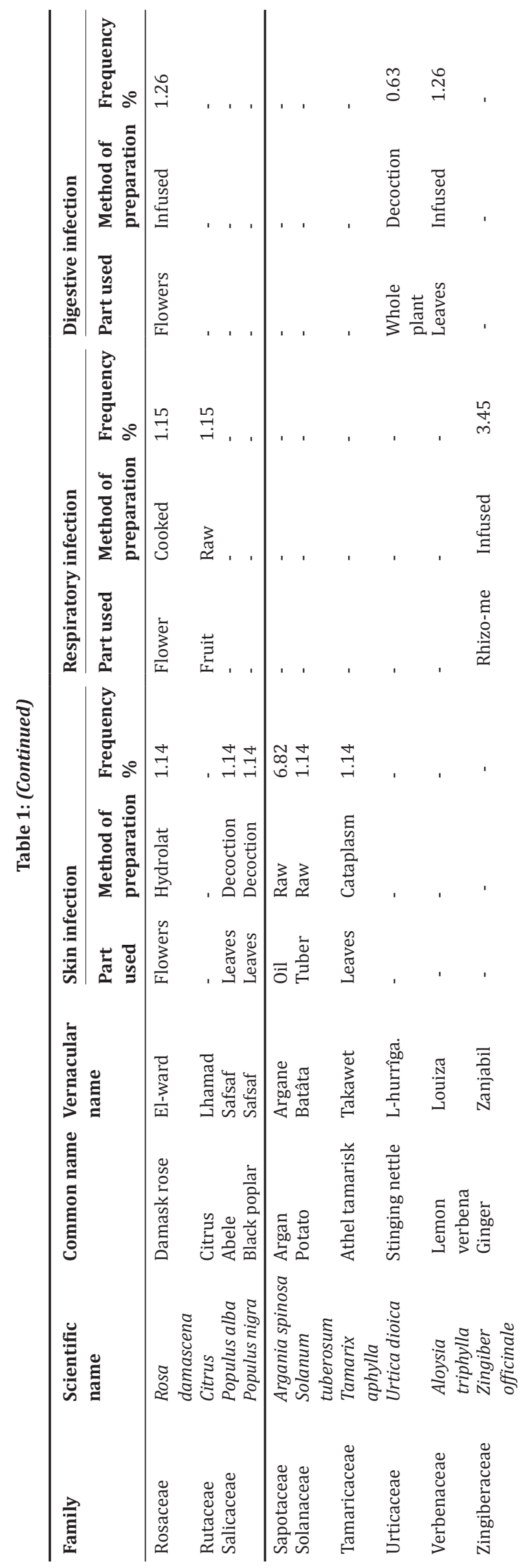

glycosides ... are within the leaves. However, unconsciousness and ignorance of most popular party and their bad actions when they practice the total harvest of the plant can lead to deforestation and the destruction of ecosystems.

As for the dose used and the method of preparation of phytodrugs, we found no notion of unit of measurement for dose, with mode decoction in most of the consumer population in the province of Sidi Kacem. However, we must note that on the one hand, the absence of accurately dose of the plant used, can have serious consequences on the health of consumers, this has been confirmed in Bel Ksiri [3]. On the other hand, the population generally grows at decoction mode. It thinks that it's adequate to warm the body and disinfect the plant $[12,20]$. This result is similar to that of ethnobotanical study in Côte d'Ivoire that indicated that decoction (19.04\%) is the mode the most used by his population, to treat respiratory diseases [21].

Furthermore, this technique can collect the most active ingredients and reduces or cancels the toxic effect of certain revenues [20]. The population, however, adopts the two modes infused and decoction against respiratory infections. This finding was mentioned in a study of treating skin infections in the central plateau of Morocco [22]. While skin infections are relieved mainly by the poultice method for the plants in direct contact with the seed coat, gives good results.

For the population of Sidi Kacem, this valuable know-how is transmitted more by heredity than by radio or other means, it refers to the experience of history as a source of information for their pain. This data, confirm the results found in a study carried in Bel Ksiri [3], according to them, the parents are the primary source of information.

Analysis of the information collected during this ethnobotanical study also enriched the Moroccan regional floristic data. This last allowed identifying 73 plant species distributed in 39 botanical families. The most used by the population studied are the families Lamiaceae, Apiaceae, and Asteraceae. These results are consistent with those found by other national studies $[2,3,7,20]$.

In addition to these three families previously cited, two other families are added for treatment of skin infections; the Alliaceae and Lythraceae. In this case, the most species reported by all informants are spontaneous like Salvia verbenaca with a $11.36 \%$, Marrubium vulgare with a frequency of $6.82 \%$, Polygonum aviculare L. and Capparis spinosa $5.68 \%$ Chenopodium ambrosioides, Ammi visnaga and Nerium oleander L. same frequency $4.55 \%$. The respondents did not specify prejudices in their use of these species, although they have a toxic effect. For example, the essential oil of $C$. ambrosioides used as anthelmintic, is fairly toxic, especially in children. The plant itself at high doses can cause signs of intolerance recalling symptoms of intoxication by essential oil [3].

While in respiratory infections dominant botanical families are Lamiaceae, Asteraceae, Alliaceae, and Myrtaceae. In comparing this result with that obtained by the study carried out in the Moroccan central plateau [22], it reflects the same trends. The family Lamiaceae dominant with 16 species used (24.61\%), and the Asteraceae family with four species $(6.14 \%)$. This type of infection is treated by a large number of informants $(27.06 \%)$, by a spontaneous plant easy to collect manually. This is found much in this area during the winter season known by the Fliu. The species belongs to the family of Lamiaceae is the Pennyroyal: Mentha pulegium L. Three other species have become important by the population for the treatment of respiratory diseases, we quote as Allium sativum, Eucalyptus globulus, and Nigella sativa, and they have a $5.88 \%$ for each. According to the information collected, they have an effective effect and don't have side effects. Intoxication by Nigel is manifested by dryness of the mouth, oropharyngeal irritation, and inflammation of the tongue, palate, tonsils and nasopharynx [3].

While digestive infections are characterized by three defined dominant families Lamiaceae, Apiaceae, and Asteraceae. These diseases are 
treated by a large number of species 47 in comparison with other infections. Among the five most frequently used species, we found three that do not characterize the region and are taken to the herbalist. We include Origanum compactum with a majority frequency of $22.58 \%$, followed by Trigonella foenumgraecum of $13.55 \%$ then $N$. sativa of $5.81 \%$. While the others two species are spontaneous and collected by traditional practitioners. They are presented in C. ambrosioides at a $7.10 \%$ and Matricaria camomilla L. at 5.16\%.

The processing of information acquired from the questionnaires sheets and the floristic identification conducted in the field, have enabled us to establish an ethnofloristic catalog Table 1, containing 73 plant species used in Sidi Kacem region for the treatment of skin, respiratory and digestive infections. In this catalog, plant species are classified according to their families following an alphabetical order, determining the scientific, common and vernacular name for each species. This inventory gives information about the used part, the method of preparation of phytodrugs and the frequency of use of the species for each type of diseases belonging in cutaneous, digestive or respiratory infections.

\section{CONCLUSION}

The ethnobotany study in Sidi Kacem area has allowed us to discover its rich flora and traditional knowledge. Moreover, to establish the floristic catalog which forms a source of information of the traditional medicinal therapy of the region. This inventory should be preserved and enriched by other studies on different types of pathologies. Morocco is known for its richness in traditional medicine. So the importance of this type of studies shall be to maintain and continue to better safeguard this heritage which can be lost with the loss of the elderly.

The interest of ethnobotanical studies also is beneficial to the discovery of new bioactive molecules, to limit the misuse of chemicals, and to protect the population against the deadly toxicity of medicinal plants.

\section{ACKNOWLEDGMENTS}

We would like to thank everyone who had helped us to achieve these studies, especially the population of the region of Sidi Kacem, for participating in our survey.

\section{REFERENCES}

1. Benabid A. Flore et Ecosystème du Maroc: Evaluation et Préservation de la Biodiversité. Paris: Ibis Press; 2000. p. 357.

2. El-Hafian M, Benlamdini N, Elyacoubi H, Zidane L, Rochdi A. Étude floristique et ethnobotanique des plantes médicinales utilisées au niveau de la préfecture d'Agadir-Ida-Outanane (Maroc). J Appl Biosci 2014:81:7198-213.

3. Benkhnigue O, Zidane L, Fadli M, Elyacoubi H, Rochdi A, Douira A. Etude ethnobotanique des plantes médicinales dans la région de Mechraâ Bel Ksiri (Région du Gharb du Maroc). Acta Bot Barc 2011;53:191-216.

4. Hmamouchi M, Agoumi A. Place des Plantes Médicinales Dans le Système de Santé au Maroc. Premier Congrès International des Plantes
Médicinales et Phytothérapie. Tunis. 1993. p. 17.

5. Bammi J, Douira A. Les plantes médicinales dans la forêt de l'Achach (Plateau central, Maroc). Acta Bot Malacitana 2002;27:131-45.

6. Rejdali M. La flore du Maroc: Etat actuel et perspectives de conservation Diversité biologique et valorisation des plantes médicinales. Éd. Actes 1996;22-17.

7. Benlamdini N, Elhafian M, Rochdi A, Zidane L. Floristic and ethnobotanical study of the medicinal flora of the High Eastern Atlas (Haute Moulouya). J Appl Biosci 2014;78:6771-87.

8. Suter G. Carte géologique de la chaine rifaine au 1/500.000. Notes et Mém Serv Géol Maroc, 245a. 1980

9. ORMVAG (Office Régionale de la Mise en Valeur Agricole) Monographie de Sidi kacem; 2007.

10. GCPH (General Census of Population and Housing). Available from: http://www.clad.hcp.ma/resultatsdurgph2004/2004. [Last accessed on 2016 Apr 14].

11. Kahouadji A. Recherches floristiques sur le massif montagneux des Beni Snassene (Maroc oriental). Université des Sciences et Techniques du Languedoc, Montpellier; 1986. p.235.

12. Lahsissene H, Kahouadji A, Tijane M, Hseini S. Catalogue des plantes médicinales utilisées dans la région de zaër (Maroc occidental). Lejeunia 2009;186:1-28.

13. Fennane M, Ibn Tattou M, Mathez J, Ouyahya A, El oualidi J. Flore pratique du Maroc, Manuel de détermination des plantes vasculaires. Rabat. Vol. I. Éd Okad, Juillet. Institute of Medical Science, University; 1999. p. 558.

14. Fennane M, Ibn Tattou M. Flore vasculaire du Maroc Inventaire et Chorologie. Rabat, Tome I. Rabat. Travaux de l'Institut Scientifique; 2005. p. 483.

15. Fennane M, Ibn Tattou M, Ouyahya A, Eloualidi J. Flore pratique du Maroc, Manuel de détermination des plantes vasculaires. Vol. II Éd. OKAD El Jadida Rabat. Travaux de l'Institut Scientifique; 2007. p. 648.

16. Fennane M, Ibn Tattou M. Flore vasculaire du Maroc Inventaire et Chorologie. Tome II. Éd. OKAD. Rabat. Travaux de 1'Institut Scientifique; 2008. p. 398.

17. Fennane M, Ibn Tattou M, El oualidi J. Flore pratique du Maroc, Manue de détermination des plantes vasculaires. Vol. III. Rabat. Travaux de l'Institut Scientifique; 2014. p. 450.

18. Mehdioui R, Kahouadji A. Etude ethnobotanique auprès de la population riveraine de la forêt d'Amsittène: Cas de la Commune d'Im n'Tlit (Province d'Essaouira). Bul Inst Sci Rabat Sec Sci de la Vie 2007;29:11-20.

19. Medisetti N, Mustafa MD. An ethnobotanical study of medicinal plant used by Koya tribesin and around Malluru hill region, Warangal district, Telangana, India. IJABPT 2016;7(2):103-14.

20. Tahri N, El basti A, Zidane L, Rochdi A, Douira A. Etude ethnobotanique des plantes médicinales dans la province de Settat (Maroc). Kastamonu Univ J Forest Fac 2012;12(2):192-208.

21. N'Guessan K, Assi-Kaudjhis C, Kouassi KH. Ethnobotanical study of antitussive plants used in traditional medicine by Abbey and Krobou populations, in the south of côte d'ivoire. IJAPBC 2015;4(2):513-22.

22. El Hilah F, Benakka F, Dahmani J, Belahbiband N, Zidane L. Étude ethnobotanique des plantes médicinales utilisées dans le traitement des infections du système respiratoire dans le plateau central marocain. J Anim Plant Sci 2015;2:3886-97. 